ordinary acetone condensation slowly occurs with formation of a ketone, the so-called pseudoionone, having the constitution $\mathrm{CII}\left(\mathrm{CH}_{3}\right)_{2} \cdot \mathrm{CH}_{2}$. CH : CH.C $\left(\mathrm{CIH}_{3}\right): \mathrm{CII} . \mathrm{CH}: \mathrm{CH} . \mathrm{CO} . \mathrm{CH}_{3}$.

Pseudoionone has a peculiar but not very pronounced smell and, when heated with a mixture of water, glycerol and sulphuric acid, undergoes conversion into an isomeric ketone, termed ionone, which possesses the constitution

$$
\begin{array}{cc}
\left(\mathrm{CH}_{3}\right)_{2} \mathrm{C}-\mathrm{CII} \mathrm{CH}: \mathrm{CH} . \mathrm{CO} . \mathrm{CH}_{3} \\
\mathrm{H}_{2} \mathrm{C} \\
\mathrm{H} \stackrel{\mathrm{C}}{\mathrm{C}}=\mathrm{CH} . \mathrm{CH}_{3}
\end{array}
$$

Ionone possesses an odour of fresh violets, which also feebly recalls that of grape blossom; it is manufactured on a large scale for use in the preparation of violet perfumes. The preparation of homologues of ionone from citral and methylethylketone has also been protected, and numerous attempts to evade the original patents have naturally been made; the use of lemongrass oil in place of citral, and of bleaching powder as a condensing agent in place of baryta, have been patented, but these patents have not been upheld by the Courts. It is a very remarkable fact that the two ketones, irone and ionone, possess odours so similar that, either when pure or diluted with alcohol, a trained nose is only just able to distinguish between them. The similarily in odour is doubtless due to the almost identical type of molecular grouning contained in the two compounds. Oil of turpentine consists essentially of a hydrocarbon of similar molecular type to irone and ionone, and it is a very noteworthy fact that turpentine, when administered internally, imparts a strong odour of violets to the urine; so far as can be ascertained, this fact has received no commercial application.

$A$ number of substances have been introduced into commerce as substitutes for musk ; of these, the first was the trinitroiso-

butyltoluene of the constitution

by nitrating isobutyltoluene, which is, in turn, prepared by the interaction of isobutyl chloride and toluene brought about by aluminium chloride. This and other trinitro-derivatives of benzenoid hydrocarbons containing two alkyl groups in the meta. position possess a powerful odour of musk, and have been used to a considerable extent in perfumery.

The investigation and manufacture of artificial and synthetic perfume materials have been only carried on to a very small extent in this country; the new industry is almost wholly of German origin. During recent years, however, France appear to have been making great strides in synthetic perfume manufac ture, and at the Paris exhibition this branch of chemical manufacture scems to be the only one in which the French exhibits equal, or even excel, those of Germany. The cause of this is obscure but may possibly be connected with the generally recognised principle that supremacy in any particular industry goes hand in hand with supremacy in the related sciences; and all students of contemporary chemical literature will agree that in Germany the science of chemistry has been in rapid decadence during recent years. A good organisation, administered by a master, accomplishes great results; but when the directing hand is gone, the very organisation itself is found to have stultified the faculty for independent thought on the part of those originally destined by nature to take the lead. Subsequently the system aids only in the filling up of immaterial details, and the pioncer work is transferred to men from quite a different school.

Little has yet been accomplished towards ascertaining the relation between the odour and the chemical constitution of sub. stances in general. IIydrocarbons as a class possess considerable similarity in odour, so also do the organic sulphides and, to a much smaller extent, the ketones. The subject waits for some one to correlate its various physiological, psychological and physical aspects in the same way that Helmholtz did for sound. It seems, as yet, impossible to assign any probable reason to the fact that many substances have a pleasant odour. It may, however, be worth suggesting that certain compounds, such as the volatile sulphides and the indoles, have very unpleasant odours because they are normal constituents of mammalian excreta and of putrefied animal products ; the repulsive odours may be simply necessary results of evolutionary processes.

W. J. P.

\section{PRIZE LIST OF THE ACADEMY OF SCIENCES.}

$A^{T}$ the annual public meeting of the Paris Academy of Sciences, on December 17, after the Presidential Address of M. Maurice Iévy, in which was a short account of the life work of MM. Milne-Edwards, Bertrand, Blanchard and Grimaux, the list of awards for the year 1900 was given.

In Geometry, the (irand Prize of the Mathematical Sciences was awarded to M. Mathias Lerch for work on the number of certain classes of quadratic forms; the Francœur Prize to $M$. Edmond Maillet, and the Poncelet Prize to M. Léon Lecornu. No memoir was received complying with the terms of the Bordin Prize. In Mechanics, the Extraordinary Prize of 6000 francs was divided between.M. Laubeuf, Charbonnier, Aubusson de Cavarlay and Grasset, M. Lerosey receiving the Montyon Prize, and Mme. Moissenet the Plumey Prize as a mark of esteem for the work done by her late husband.

In $\Lambda$ stronomy, the Lalande Prize was adjudged to M. Giacobini for his work on comets ; the Damoiseau Prize to M. J. von Hepperger for his work on the influence of the planets upon comets : the Valz Prize to M. l'Abbé Verschaffel for work done ar the Abbadia Observatory; the Janssen Prize to Prof. Barnard for his brilliant discovery of the fifth satellite of Jupiter.

In Statistics, the Montyon Prize has been awarded to M. du Maroussem, the works of M. Barras, M. Laussedat and M. Pailhas receiving honourable mention.

In Chemistry, M. Bćhal receives the Jecker Prize, and in Botany, M. H. Bruchmann the Desmazières Prize, M. Gyula Istvanf having a very honourable mention. The Montagne Prize is divided between .I.M. Delacroix and Boistel. In Anatomy and Zoology the Thore Prize is awarded to M. Seurat for his researches on the parasitical larvæ of the Iymenoptera, and the Da Gamo Machado Prize to Mme. la Comtesse de Linden, M. Siedlecki, M. P. Carnot and M. Bordas, the Savigny Prize not being awarded.

In Medicine and Surgery, Montyon Prizes are adjudged to MM. Hallopeau and Leredde, for their treatise on dermatology; II. Guilleminot, for his work on the medical applications of the $\mathrm{X}$-rays; and M. Joules Soury, for his book on the central nervous system. In connection with these prizes, mentions are accorded to $\mathrm{M}$. Nobécourt, for his work on the pathogeny of the gastro-intestinal diseases of young children; M. Sabrazès, for his work on the origin of blood corpuscles; and M. Gallois, for a book on scrofula and odenoidal diseases; MM.'CCunéo and Toulouse receiving citations. The Barbier Prize is divided between M. Marage, for a memoir on the theory of vowel formation, and M. Guinard, for a pharmacodynamic study of morphine and apomorphine, a mention being accorded to MM. Bræmer and Suis. In default of the discovery of an absolute specific for cholera, the arrears of interest on the Bréant Prize are divided between M. Auclair, for researches on the toxic substances contained in tubercle bacilli, and M. Paul Remlinger, for a memoir on some rare complications of dysentery, and the association of dysentery with typhoid fever. The Godard Prize is given to M. Léon Bernard, for his researches on the functions of the kidney in chronic nephritis; the Parkin Prize to $M$. Henri Cuupin, for work done in plant physiology; the Dusgate Prize to M. Icard, for methods of diagnosis of real and apparent death; the Baron Larrey Prize to MM. Nimier and Laval, for three works on projectiles and explosives; the Bellion Prize being divided between M. J. Brault, for his treatise on tropical diseases, and M. Samuel Gache, for his treatise on workmen's dwellings in Buenos Ayres; the Lallemand Prize between M. Maurice de Fleury, for various treatises on medicine, and M. de Vabias, for his researches on the nervous system of aquatic gasteropods. Honourable mentions are accorded to MM. Knopf, Jacquet and M. Finck.

In Physiology the Montyon Prize is divided between M. Pachon for studies on cardiac and vascular mechanism and Mdlle. Jotéyko for memoirs on nervous effort and fatigue, and the Philipeaux Prize between M. Delezenne for his reseaches on anti-coagulating substances and M. Niclonx for experimental researches on the elimination of alcohol in the organism, M. Roussy receiving honourable mention; the Pourat Prize is awarded to MM. Bergonié and Sigalas for a determination of the principal anthropometric data; and the Martin-Damourette Prize to M. Long for his studies on the central paths of general sensibility. In Physical Geography, M. Lugeon receives the Gay Prize for his theory on the origin of Alpine valleys.

Among the General Prizes, a Montyon Prize is award ad to

No. I 626 , VOL. 63$]$ 
M. Tnllat for his applications of formaldehyde to industry, and to MM. Sévène and Cohen for their use of phosphorus sesquisulphide in the manufacture of matches in the place of ordinary phosphorus; the Cuvier Prize to .I. Antoine Fritsch for his treatises on European Birds and on Palæontology, the Wilde Prize to M. Delépine, for his experimental researches on aldehydes; the Vaillant to M. Henri Gautier, for his work on alloys and on the atomic weight of boron; and to M. F. Osmond, for his researches on iron and steel; the Frémont Prize to M. Ch. Frémont, for his results on the testing of the resistance of metals; the Gegner Prize to Mme. Curie; the Delalande-Guérineau P'rize to M. Maurain and M. Lacombe. for their work on the measurement of an arc of meridian at Quito ; the Jérome Ponti Prize to MIM. P. Girod and Massénat; the Tchihatchef Prize to M. de Loczy, for work on the Physical Geography and Geology of Fastern China; the Houllevigne Prize to M. IVallerant, for his researches in Crystallography. The Boileau Prize is divided between M. Sautréaux, M. Delemer and M. Nau; the Cahours Prize between M. Mouneyrat, M. Metzner and M. Defacq\%.

The Saintour Prize is atwarded to $M$. Debureaux, the prize founded by the Marquice De Laplace to M. Macaux, and the prize founded by M. Fé'ix Revot to MMI. Macaux, de Schlum berger, Martinet and Hardel.

\section{UNITED STATES GEOLOGICAI, SURVEY.}

THE work of the Geolngical Survey of the United States comes before us in almost overwhelming amount, and yet, as we take note of the publications, we have nosentiment but that of admiration for the evidence they give of brilliant, useful and painstaking research : research, too, of very varied character.

\section{Bulielins.}

A dozen numbers of the Bulletin, dated 1898 and 1899 , have all been received since midsummer of this year.

Nos. 156 and 162 on the Bibliography of North American Geology for 1897 and 1898 , contain the titles with, in many cases, brief notes of the contents of all geological publications dealing with the United States and Canada. Seven hundred and forty-two articles are recorded for 1897 , and 941 for 1898 . Here, indeed, is the index to a vast amount of information, which to be made available for general reference requires, ultimately, to be tabulated and summarised under many subjects.

Bulletin No. 154 is "A Gazetteer of Kansas," containing list of all hamlets, post villages and townships, with, as far as possible, notes of their area, population and altitude; the whole prefaced with general statistics. No. I 60 is the third edition of "A Dictionary of Altitudes in the United States," a work of 775 pages, arranged al phabetically, according to the localities in the several States. In Nos. 155 and $16 \mathrm{I}$ we find records of the earthquakes which happened in California in 1896,1897 and 1898 . A scale, divided into ten numbers, is given for estimating the intensity of shocks Thus No. vi. notes "general a wakening of sleepers; general ringing of bells; swinging of chandeliers; stopping of clocks; visible swaying of trees; some nervous persons run out of buildings; window glass broken "; while No. $x$. tells of "Great disasters ; overturning of rocks ; fissures in the surface of the ground ; mountain slides."

We pass on to other Bulletins, and in No. 152 have "A Catalogue of the Cretaceous and Tertiary Plant; of North America," by Mr. F. H. Knowlton; and in No. 152, "A Bibliographic Index of North American Carb.niferous Inverte. brates," by Mr. Stuart Weller. These works must prove of the greatest value for reference. They are clearly printed, the synonyms are recorded, and there are lists of works on the subjects dealt with.

Uther numbers of the Bulletin are of a different character. In No. 15 I we have an account of "The Lower Cretaceous Gryphreas of the Texas Region," by Messrs. R. T. Hill and T. W. Vaughan. Fossil oysters have always been regarded as a troublesome and variable group, mainly, as the authors be. lieve, because they have not been properly understood and classified. These fossils are, however, important, not merely from a zoological, but from a stratigraphical point of view, as shown by certain deep borings for artesian water in Texas. Abundant material is to $h$ : found in that country for their study. They lie strewn upon the surface in such numbers that they are

No. I626. VOL. 63] sometimes used for road material or collected and burned into lime. Extensive masses of indurated strata are composed of them. The pebbles in the streams are largely made up of oysters. They represent many genera and species, and are of all sizes, from individuals less than an inch in length to shells which weigh 5 lbs. and more. They are found at various horizons throughout 4000 and more feet of rocks constituting the Cretaceous system in Texas. There is thus ample material for a study of the fossils from a phylogenetic and morphologic standpoint, and the authors here give their special attention to the Gryphases. The work is admirably illustrated, and it is not obscured in any way by the indiscriminate naming of specimens.

No. 157, on "The Gneisses, Gabbro-schists and Associated Rocks of South-western Minnescta," by Mr. C. W. IIall, No. I 58, on "The Moraines of South-eastern South Dakota," by Mr. J. E. Todd, and No. I59, on "The Geology of Eastern Berkshire County, Massachusetts," by B. K. Emerson, are all well illustrated, full of information of local importance and of much that is of general interest.

\section{Indiana R'eport.}

The geology and natural resources of Indiana are treated of by Mr. W. S. Blatchley, the State geologist, in the twenty fourth annual report of the department (1899). The volume is one of 1078 pages, and is largely occupied with a catalogue, by $\mathrm{Mr}$. S. Coulter, of the flowering plants and of the ferns and their allies indigenous to Indiana. A considerable portion is also taken by a descriptive and illustrateri catalogue of the mullusca of the State, by Mr. R. F. Call. These include a large number of Unios. The dragon flies of Indiana are enumerated and described by Mr. E. B. Williamson, and there are notes on the batrachians and reptiles of Vigo county, by Mr. W. S. Blatchley, The economic resources of Indiana include coal, petroleum, natural gas, stone and clays. The amount of natural gas is restricted, and a failure of supply is expected. A great increase of activity in the coal regions is noted. There is estimated to be forty billions of tons of coal in Indiana, of which one-fifth is reckoned as workable under present conditions. Excellent coal for steam and household purposes and for blast-furnaces is obtained. Dr. A F. Foerste contributes an article on the Middle Silurian rocks of the Cincinnati anticlinal.

\section{U.S. Annual Ricports.}

Parts i., iv. and vi., and portions of Part ii. of the nineteenth annual report were noticed in NATURE for April 19. We have since received Parts ii., iii. and v., four volumes, including an atlas. Part ii., which comprises $95^{8}$ pages and 172 plates, is somewhat heavy and unwieldy as a work of reference. O articles not previously noticed, one by Mr. C. W. Hayes deals with the physiography of the Chattanooga district in Tennessee, Georgia and Alabama. The city of Chattanooga lies almost in the centre of this district, and the term physiography is used in a purely geographical sense. The article is an essay on denudation, written according to the principles of modern geography. The author deals with the formation of three successive peneplains, and shows how the drainage has been modified and diverted until the present topographic features were developed. The peneplains are considered as the product of subaërial erosion. The term geomorpholugy is used for the description, classification and correlation of the land forms; and geomorphogeny for the natural processes by which these forms have been developed. The author gives definitions of other physiographic terms, which are being introduced at a somewhat alarming rate.

Another article in Part ii. is on the (ieology of the Richmond Basin, Virginia, by Messrs. N. S. Shaler and J. B. Woodworth. The area is important from an econumic point of view as it contains the only free-burning coal immediately a tjacent to tidewater in the eastern portion of the United States. The strata are of Jura-Trias age, the fossils from the lower portion of them being more closely related to the Rhietic deposits of Europe than to those of any other horizon. The beds are grouped as the Newark formation, and they rest locally on a surface of igneous and crystalline rocks. Natural coke occurs in the strata, and is due to the intrusion of igneous rocks; it is denser than artificial coke. The bituminous coals are sharply parted from the cokes as the effects produced by the igneous rocks end abruptly. Mr. F. H. Knowlton contributes some notes on fussil coniferous wood from the Richmond Basin. 